Sherwood, Peter. "Kiséry, András, Zsolt Komáromy and Zsuzsanna Varga, eds. 2016. Worlds of Hungarian Writing

- National Literature as Intercultural Exchange. Madison, NJ: Fairleigh Dickinson University Press and Lanham,

MD: Rowman and Littlefield. 272 pp.." Hungarian Cultural Studies. e-Journal of the American Hungarian

Educators Association, Volume 10 (2017): http://ahea.pitt.edu DOI: 10.5195/ahea.2017.298

\title{
Kiséry, András, Zsolt Komáromy and Zsuzsanna Varga, eds. 2016. Worlds of Hungarian Writing - National Literature as Intercultural Exchange. Madison, NJ: Fairleigh Dickinson University Press and Lanham, MD: Rowman and Littlefield. 272 pp.
}

\author{
Reviewed by Peter Sherwood*, László Birinyi, Sr., Distinguished Professor of Hungarian \\ Language and Culture (Emeritus), University of North Carolina at Chapel Hill
}

To the best of my knowledge the number of postwar English-language essay collections devoted to Hungarian literature can be counted on (even fewer than) the fingers of one hand. While Joseph Reményi's posthumously published Hungarian Writers and Literature (1964) is now seriously outdated (and was, indeed, already so when it appeared), two other collections have stood the test of time somewhat better. A Journey into History: Essays on Hungarian Literature (New York: Peter Lang, 1990), edited by Moses M. Nagy, is still worth seeking out for a few papers (especially the late Mihály Szegedy-Maszák's bravura introduction to "Romanticism in Hungary"), while Hungarian Literature, edited by Enikö Molnár Basa in the Review of National Literatures series (New York: Griffin House Publications, 1993), offers, among other contributions, a still-valuable piece by Péter Dávidházi on "The Ideal of Literature in Hungarian Criticism," as well as George F. Cushing's lucid "The Role of the National Poet," with Sándor Petőfi and Gyula Illyés as examples.

However, as the titles of the essays suggest, these collections are fairly traditional, by which I mean that they tend to "expound" the "national literature" of an "exotic" language to an English-language readership that is assumed to know little or nothing about either. Moreover, even the most recent of these volumes appeared a quarter of a century ago, and in the meantime the world, and along with it Hungary and the form and content of Hungarian literature and literary studies have changed radically. Nothing epitomizes this turn more starkly than the title of the three-volume collection edited in 2007 by Szegedy-Maszák entitled A magyar irodalom történetei ['Histories of Hungarian Literature'], which abandons the notion of the grand récit of a Hungarian "national literature" that can be said to have begun with the work of Ferenc Toldy, notably his A magyar nemzeti irodalom története ['History of Hungarian National Literature'] (Budapest: Emich, 1885), and reached its apogee a century later in two fairly conventional histories, curiously enough both of them in English: Tibor Klaniczay (ed.), A History of Hungarian Literature (Budapest: Corvina, 1983) and Lóránt Czigány, The Oxford History of

*magyarize@gmail.com

$($ (c) $)$ EY

ULIS D-Sorke
New articles in this journal are licensed under a Creative Commons Attribution 4.0 International License.

This journal is published by the University Library System of the University of Pittsburgh as part of its D-Scribe Digital Publishing Program and is cosponsored by the University of Pittsburgh Press 
Sherwood, Peter. "Kiséry, András, Zsolt Komáromy and Zsuzsanna Varga, eds. 2016. Worlds of Hungarian Writing

- National Literature as Intercultural Exchange. Madison, NJ: Fairleigh Dickinson University Press and Lanham,

MD: Rowman and Littlefield. 272 pp.." Hungarian Cultural Studies. e-Journal of the American Hungarian

Educators Association, Volume 10 (2017): http://ahea.pitt.edu DOI: 10.5195/ahea.2017.298

Hungarian Literature From the Earliest Times to the Present [in the online version: to the mid1970s] (Oxford: Clarendon Press, 1984; second, revised edition 1986).

Narratives such as these, which see Hungarian literature as an organic, self-enclosed development of autochthonous movements and traditions within the boundaries of a nationallinguistic community, have in the last two decades been superseded by scholarship in the spirit of the above-mentioned, symptomatic 2007 work. This latter consists, as the plurality in its title (Histories) suggests, of a series of more or less stand-alone essays that include (beyond detailed coverage of nineteenth- and twentieth-century literature in Hungarian) accounts of the "fate in Hungary" of, for example, Ossian, Brecht, the modern German novel, as well as attention to the literature of Hungarian writers in the countries adjacent to Hungary and in the diaspora (the latter previously dealt with only in Czigány's magnum opus). The 2007 Histories of Hungarian Literature collection casts its net broadly enough to include an essay by Editor-in-Chief Szegedy-Maszák on Tibor Fischer, an English-language novelist with a Hungarian background, who has never written a word in Hungarian.

It is against this backdrop that the present collection should be seen. In this volume, an Introduction by the editors is followed by twelve articles ranging, perhaps a little dizzyingly, from William Wordsworth to Péter Esterházy and offering fresh and lively perspectives, in particular (though not solely) in response to the growing interest in Hungarian literature in the Anglophone world and, indeed, elsewhere. In this review I will attempt to give a brief account of the impressive Introduction and, since few readers are likely to read this work from cover to cover, I intend, in the interest of fairness and acknowledging the immense amount of labor that has clearly gone into this pioneering project, to point out at least the topic and main argument of every article.

The editors' Introduction is a model of its kind. Reading it, I found myself nodding in vigorous agreement throughout and underlining virtually every sentence, so I find it particularly difficult to summarize. Beginning by pointing out, as mentioned above, that Hungarian literary historiography has been until recently defined by the framework of one national literary history, the Introduction characterizes the present collection as a "nonsystematic survey of modern Hungarian literary culture as a scene of cultural exchange" (1) and signaling that while most of the contributors learnt Hungarian as their first language, all of them have lived extra Hungariam, hence "the existential condition of this collection is thus an aspect of the cultural condition it seeks to explore" (2). The recent international, and especially Anglophone, interest in Hungarian literature (notably in the works of the leading quartet of Esterházy, Kertész, Nádas and Krasznahorkai, though I would say there are enormous differences in the penetration and understanding of this quartet by the Anglophone market) is then characterized as a result of the globalization of literary production. The editors suggest that, like other writers in "nonhegemonic" cultures, Hungarian authors enter the twenty-first century marketplace of world literature because their writing has been shaped by its participation in an "accelerating exchange" with other literary cultures, though increasingly as East or Central European writers rather than as representatives of a unique, national tradition.

The next point made in the Introduction is even more striking: that the life of Hungarian literary works in translation demands a rethink of our understanding of Hungarian national literary culture, traditionally regarded as the most prestigious institutional expression of the 
Sherwood, Peter. "Kiséry, András, Zsolt Komáromy and Zsuzsanna Varga, eds. 2016. Worlds of Hungarian Writing - National Literature as Intercultural Exchange. Madison, NJ: Fairleigh Dickinson University Press and Lanham, MD: Rowman and Littlefield. 272 pp.." Hungarian Cultural Studies. e-Journal of the American Hungarian Educators Association, Volume 10 (2017): http://ahea.pitt.edu DOI: 10.5195/ahea.2017.298

national language. The evidence for this is provided in part by the self-positioning of the most noted "Hungarian literature" writers as well as the habit of measuring literary success - even within Hungary - by international reception of their works (even under communism, literary encyclopedias religiously listed all the languages into which every work had been translated, from Mandarin to Macedonian). The examples include the quartet mentioned above, but interculturality is also claimed to be more than an enabling factor or influence in the case of the work of writers like Árpád Kun, Zsófia Bán and Ferenc Barnás: increasingly it is the thematic substance of their works and their existential condition. Kun, for example, moved from Hungary to Norway, an experience drawn on in his 2014 hit Boldog észak ['Blissful North']. Bán, who teaches American literature in Budapest and is in many ways a literary kinswoman of AngloGerman writer W.G. Sebald, was born in Brazil, studied in Portugal and the United States, and has been extensively translated into German. And Barnás's early work Bagatell tells the itinerant life of a street musician. Thus, the editors' rather ambitious dual aim is "to open up Hungarian literary culture to foreign, Anglophone readers by highlighting its intercultural contexts, but also to identify some of the ways in which such contexts may broaden the understanding of a national literary culture from a vantage point within that culture" (9).

A further, necessary section of the Introduction thoughtfully surveys the crucial yet continuously changing role played by translations from Western European literatures in the establishment of a Hungarian national literature from the late eighteenth century onward, and how the kind of traditional scholarship that used to focus on "how X (a Western writer) influenced Y(a Hungarian writer)" or "the reception of X (a Western writer) in Hungary" products of intercultural exchange - has now been supplanted by a newer understanding of national literature as the very process of that exchange. This is illustrated by contrasting Sándor Maller's early work on translations of Ossian, suggesting that its reception in Hungary was enabled by the historical pessimism that characterized Hungarian national poetry of the time, with the work of Gabriella Hartvig, who established that Ossian's early reception in Hungary was determined by the influences of Latinate classicism, Austrian Jesuit poetry, and the Austrian and Hungarian reception of Milton's Paradise Lost.

The Introduction then moves on to consider more theoretical aspects of reception and influence study as well as literary theory as practiced by adherents of German hermeneutics. This path leads into an enlightening examination of the work of German-Hungarian critic Hugo Meltzl (1846-1908). Together with the "last Hungarian polymath" Sámuel Brassai (1897-1897), between 1877 and 1888 Meltzl founded the world's first journal of comparative literature, Összehasonlító irodalomtörténeti lapok ['Journal of Comparative Literary Studies'], published in the symptomatically trilingually named Transylvanian capital of Kolozsvár/Cluj/Klausenburg, first in six and later in ten languages (see further on this issue the article by Ana-Mária Codău, "The Acta Comparationis Litterarum Universarum (1877-1888) from the Perspective of its Relations with English Literature," at: http://ahea.pitt.edu/ojs/index.php/ahea/article/view/299)

The collection's first four articles are devoted to the nineteenth-century worlds of Hungarian writing. In '"Wordsworth in Hungary' - An Essay on Reception as Cultural Memory and Forgetting," Zsolt Komáromy notes that in fact Wordsworth "has no Hungarian reception to speak of" and therefore treats him in terms of his place in what Jan Assmann (whose influential work is mentioned in several of the articles in the collection) has theorized as collective memory 
Sherwood, Peter. "Kiséry, András, Zsolt Komáromy and Zsuzsanna Varga, eds. 2016. Worlds of Hungarian Writing - National Literature as Intercultural Exchange. Madison, NJ: Fairleigh Dickinson University Press and Lanham, MD: Rowman and Littlefield. 272 pp.." Hungarian Cultural Studies. e-Journal of the American Hungarian Educators Association, Volume 10 (2017): http://ahea.pitt.edu DOI: 10.5195/ahea.2017.298

or cultural memory, which offers a heightened awareness of the formative power of national narratives. Veronika Ruttkay's exemplary piece of close reading, "Negotiating the Popular/National Voice - Impropriety in Two Hungarian Translations of Robert Burns," considers, among other important issues, the role played by Burns in the conceptualization of Hungarian literary populism and thus sheds important light on the "popular-national" movement in nineteenth-century Hungarian poetry. Zsuzsanna Varga's "Translation, Modernization, and the Female Pen - Hungarian Women as Literary Mediators in the Nineteenth Century" provides, inter alia, a timely and lively introduction to two leading women of the post-1849 Hungarian emigration. The first is Theresa Pulszky, who played an important role alongside Lajos Kossuth in tandem with her husband Ferenc, not least as co-author with him of several English-language books of enduring value. The second is Júlia Podmaniczky, wife of Baron Miklós Jósika, the "father of the Hungarian historical novel," whose written legacy is more diffuse but, like Theresa Pulszky's, is still underrated and under-researched. This is perhaps the place to note the welcome fact that two-thirds of the contributors to this volume are women. The final article on the nineteenth-century worlds of Hungarian writing is Julia Bacskai-Atkari's impressively wideranging "The Hungarian Verse Novel in a Cross-Cultural Perspective," devoted to a European genre that embraces, for example, Alexander Pushkin's Eugene Onegin and Byron's Childe Harold. Bacskai-Atkari suggests that Hungarian examples of the verse novel, such as Arany's Bolond Istók ['Crazy Istók'], are distinct from the Russian and English works in that unlike the former they evolved in the absence of a national epic.

The volume moves into the twentieth century with Ágnes Vashegyi MacDonald's "Antal Szerb's The Queen's Necklace - A 'True Story' of Cross-Cultural Intersections in Hungarian Literature." In the last two decades Szerb's novels have resonated in the Anglophone world with the outstanding translations of Len Rix and recently an English-language selection of Szerb's essays on European literature (Reflections in the Library - Selected Literary Essays 1926-1944, trans. Peter Sherwood; Cambridge, UK: Modern Humanities Research Association, 2016) has begun to round out Szerb's remarkable career for the Anglophone reader. So it is very good to have a consideration of what Vashegyi MacDonald calls a "unique experiment in Szerb's oeuvre" (109), meaning a blend of elements from historical scholarship and novelistic narrative. This article whets one's appetite for more about the author's views on Szerb's better-known works, such as Utas és holdvilág ['Journey by Moonlight'], which, with its rich panoply of allusions to Keats, Shelley and Goethe in the framework of the Bildungsreise and memory, also has much to offer in a cross-cultural perspective. A completely different kind of work is Sándor Hites's perceptive article on a number of Hungarian literary scholars who lived and published in exile, "Mediation and Hybridity - Twentieth-Century Hungarian Émigré Literary Scholars." Hites persuasively argues that in the condition of exile, comparativism can successfully challenge the tunnel vision of national philologies. In "The New Left's Use and Abuse of György Lukács's Thought," György Túry suggests that Hans Magnus Enzensberger's reading of Lukács informed the (semi-)official reception of Western "New Left" thinking in Cold War Hungary. Tamás Demény's comparative discussion of Hungarian Roma and African-American autobiographies shows how minority literatures can infuse national cultures with a "hybrid identity." Demény's article is particularly noteworthy for its discussion of Roma life-writing, a neglected aspect of the above-mentioned histories of Hungarian literature. 
Sherwood, Peter. "Kiséry, András, Zsolt Komáromy and Zsuzsanna Varga, eds. 2016. Worlds of Hungarian Writing

- National Literature as Intercultural Exchange. Madison, NJ: Fairleigh Dickinson University Press and Lanham,

MD: Rowman and Littlefield. 272 pp.." Hungarian Cultural Studies. e-Journal of the American Hungarian

Educators Association, Volume 10 (2017): http://ahea.pitt.edu DOI: 10.5195/ahea.2017.298

Coming now closer to the recent past, Györgyi Horváth's "The Cultural (Un)Turn in Hungarian Literary Scholarship in the 1990s - Strategies of Inclusion and Exclusion" and Edit Zsadányi's "Borderline Fiction - Eastern Europe and East-West Encounters in László Krasznahorkai's Works," both in their different ways focus on the perception of Hungary as a "borderland," with the former article claiming that Hungary should be seen as a site of negotiation between the global and the local, while the latter suggests that Krasznahorkai's universalizing claims for his country help preserve its local heritage in a globalizing world. The often-cited difficulty of Krasznahorkai's work and the quite astonishing plaudits it has garnered in English translation indicate that a major English-language study of his work that (unlike Zsadányi's article) also treats Seiobo járt odalent ['Seiobo There Below'] and Báró Wenckheim hazatér ['Baron Wenckheim Returns'] is now overdue. Lauren Walsh's subtle study, "Text, image, Memory - Intermediality in the work of Péter Nádas," examines the relationship between personal and cultural memory in Nádas's Own Death and A Lovely Tale of Photography, both of which involve literature as well as photography, the latter being a major interest of Nádas's. Here, too, parallels between personal and collective memory are productively explored. The final article, Katalin Orbán's "Monument and Bulldozers - Social Memory Landscapes in Péter Esterházy's Celestial Harmonies and Donald Barthelme's The Dead Father" demonstrates how this important postmodernist's treatment of the father figure in his best-known work is shaped partly by its intertextual relationship with an experimental novella by American writer Donald Barthelme. While this article does relate to the topic of the collection as a whole in the sense that it is ultimately concerned with cultural memory, it has a fairly narrow focus, and more studies in English about Esterházy's as well as about Nádas's work from these scholars, and possibly others, would be welcome. Such studies, preferably broader in scope than the present articles, might also go some way toward explaining why these two writers, central to contemporary Hungarian literature, have not really "made it" in English translation, at least not in the way that Krasznahorkai has. (It is remarkable, for instance, that the English translations of the two works discussed by Lauren Walsh were published outside the Anglophone area, in Germany and in the Czech Republic, respectively.)

In conclusion, while this is hardly a book for the casual browser, those with an interest in any of the authors or topics surveyed in this review will find that the relevant chapter repays the concentration required to profit from it, and that nearly all of the Introduction can be recommended without reservation. Certainly, the volume's capacious framework makes available a wide range of material on what we should now perhaps call "literature in Hungary/Hungarian." Although the inherent difficulty of some of the articles is occasionally compounded by grammatical or stylistic infelicities, this volume nevertheless deserves a place in the library of every university that offers courses in comparative literature, as nothing remotely like it is currently available. 